\title{
Idea zrównoważonego rozwoju w encyklice Laudato si'
}

\author{
Artur Pawłowski \\ Wydział Inżynierii Środowiska Politechniki Lubelskiej, \\ Zakład Zrównoważonego Rozwoju, ul. Nadbystrzycka 40B, 20-618 Lublin, a.pawlowski@wis.pol.lublin.pl
}

\section{Streszczenie}

Encyklika Laudato si' to najważniejszy dokument Kościoła katolickiego ostatnich lat. Poruszając problem zagrożonego prawidłowego rozwoju człowieka, papież Franciszek odwołuje się do koncepcji rozwoju zrównoważonego i integralnego. Wskazuje na powiązanie zagrożeń środowiskowych z kwestiami ogólnorozwojowymi, ekonomicznymi i społecznymi. Podkreśla szczególne znaczenie przepaści, jaka dzieli bogatych od biednych, nawołując do respektowania potrzeb i praw całej rodziny ludzkiej. Wzywa do odrzucenia globalizacji obojętności, przekonując, że zmiana jest możliwa - dla wspólnego dobra nas wszystkich.

\section{Stowa kluczowe}

encyklika Laudato si', rozwój zrównoważony, Kościół katolicki, sprawiedliwość

\section{Wprowadzenie}

Koncepcja zrównoważonego rozwoju została sformułowana w 1987 roku w raporcie Światowej Komisji ds. Środowiska i Rozwoju ONZ Nasza wspólna przyszłość. Publikacja ta stanowiła próbę oceny kondycji, w jakiej pod koniec XX wieku znajdowała się światowa społeczność. Przestrzegano przed powszechnie przyjętym wąskim rozumieniem pojęcia „rozwój” (uwzględniającym tylko rozwój czysto ekonomiczny i paradygmat wolnego rynku), a także przed równie wąskim podejściem do pojęcia „środowisko”. We współczesnym świecie - jak dobitnie w komentarzu z ramienia OECD podkreślał Donald J. Johnston - „środowisko nie jest sferą niezależną od ludzkich działań, ambicji i potrzeb" (Web-01). Współczesne sytuacje kryzysowe (w aspekcie środowiskowym, rozwojowym, rolniczym, społecznym, czy energetycznym) także nie są od siebie niezależne. To jest jeden kryzys globalny wynikający z niewłaściwego podejścia człowieka do środowiska. W raporcie za szansę na lepszą przyszłość uznano ideę zrównoważonego rozwoju, definiując go jako taki, który gwarantuje zaspokojenie potrzeb obecnych pokoleń, lecz nie ogranicza możliwości zaspokajania potrzeb przyszłych pokoleń. To ogólne sformułowanie od strony etycznej reprezentuje stanowisko antropocentryzmu umiarkowanego (punktem wyjścia jest tu człowiek, a nie środowisko). Zostało ono uszczegółowione w ramach trzech grup problemowych: ekologicznej, ekonomicznej i społecznej. Ujmując to inaczej, za Tadeuszem Borysem, zrównoważony rozwój należy rozumieć jako dążenie do osiągnięcia zintegrowanego ładu, którego elementami byłyby łady ekologiczny, ekonomiczny 
i społeczny (Borys 1998: 94-95). I choć przyjmowanych w literaturze definicji zrównoważonego rozwoju odnaleźć można wiele, powszechnie przyjęta jest tylko jedna z nich - właśnie ta pochodząca z raportu Nasza wspólna przyszłość. Do niej odwołują się bowiem dokumenty ONZ, strategie UE, a w Polsce umieszczono ją nawet w Konstytucji RP.

\section{Zrównoważony rozwój a Kościół katolicki}

Zagadnienia zrównoważonego rozwoju są doskonale widoczne w społecznej nauce Kościoła katolickiego. Jest to szczególnie istotne, ponieważ motywacje działań podejmowanych przez każdego człowieka wynikają nie tylko z ram obowiązującego prawa, ale także z indywidualnych przekonań i akceptowanych wartości, w których kształtowaniu szczególną rolę odgrywa religia.

Do 2016 roku Kościół katolicki przedstawił blisko 500 dokumentów, które odnosiły się do zagrożeń środowiska naturalnego lub umieszczały dyskusję w szerszym kontekście zagrożeń dla prawidłowego rozwoju człowieka.

\section{Zrównoważony rozwój a encyklika Laudato si'}

Najnowsza encyklika papieża Franciszka Laudato si' doskonale wpisuje się w ten nurt, stanowiąc kontynuację prac Jana Pawła II (począwszy od encykliki Sollicitudo rei socialis) i Benedykta XVI (encyklika Caritas in veritate). Co więcej, wydaje się, że to najważniejszy dokument Kościoła katolickiego ostatnich lat.

Właściwie cała encyklika odnosi się do kwestii zagrożonego prawidłowego rozwoju człowieka, przy czym bezpośrednie odniesienie do zrównoważonego rozwoju (bądź ogólniej do pojęcia zrównoważoności) pada w tekście 19 razy. Przeanalizujmy wybrane fragmenty encykliki.

Papież pisze, że „nie można mówić o zrównoważonym rozwoju bez solidarności między pokoleniami”. To bezpośrednie nawiązanie do przytoczonej już definicji z 1987 roku, a zarazem wskazanie istotnej słabości wielu obecnie przyjmowanych strategii. Błędem jest ograniczanie problematyki zrównoważonego rozwoju tylko do ochrony środowiska (co jest widoczne w wielu pracach naukowych, szczególnie polskich). Ale równie istotny jest kontekst przyszłych pokoleń. Nienarodzeni nie mogą zabrać głosu w swojej obronie, ale to od nas zależy, jaki świat pozostawimy im w spadku. Tymczasem wiele współczesnych strategii zbyt mocno koncentruje się na tym, co „dziś”, zapominając o tym, co ,jutro".

Kolejny cytat precyzuje ważne problemy: „Naglące wyzwanie ochrony naszego wspólnego domu obejmuje troskę o zjednoczenie całej rodziny ludzkiej w dążeniu do zrównoważonego i zintegrowanego rozwoju, ponieważ wiemy, że wszystko może się zmienić. [...] Zastanawiające, jak to możliwe, że ubiegamy się o budowanie lepszej przyszłości, nie myśląc o kryzysie środowiska i cierpieniach ludzi zepchniętych na margines społeczeństwa”.

Po pierwsze, należy podkreślić, że w wielu miejscach encykliki papież Franciszek rozszerza termin „zrównoważony rozwój”, pisząc o rozwoju zrównoważonym i zintegrowanym. Jest to ważny krok, biorąc pod uwagę, że oryginalny angielski termin sustainable development bywa w innych językach różnie tłumaczony, a przyjmowane terminy czasem nie do końca odzwierciedlają jego pełne znaczenie (np. ograniczając się tylko do aspektu trwałości).

Po drugie, cytowany fragment ukazuje pozytywne przesłanie, z jakim zwraca się do nas papież. Niezależnie od skali zagrożeń, których jesteśmy świadkami, pamiętajmy, że „wszystko może się zmienić”. I powinno, wszak we współczesnym świecie bogactwo osiągnęli jedynie nieliczni, a stało się to kosztem degradacji środowiska i rosnącego ubóstwa większości. Mimo ogromnej ilości produkowanej żywności, bogaci niechętnie się nią dzielą. Nadal ponad 1 mld ludzi nie zarabia więcej niż 1\$ dziennie, dochód kolejnych 3 mld nie przekracza $2 \$$. W konsekwencji 1 mld mieszkańców naszej planety 
cierpi z powodu niedożywienia. Codziennie przyczyną śmierci wielu ludzi jest właśnie głód.

Problem biedy nie dotyczy tylko krajów afrykańskich. W 2015 roku w mediach pojawiło się niepokojące doniesienie z Hiszpanii. Niektórzy tamtejsi pracodawcy doszli do wniosku, że wobec wysokiego bezrobocia płacenie za wykonywaną pracę nie jest już potrzebne. Swoim potencjalnym pracownikom oferują tylko wyżywienie i miejsce do spania, a mimo to chętnych nie brakuje (Web-02). Nawet w uznawanym za najbogatsze społeczeństwie amerykańskim bieda jest codziennością dla aż 50 mln obywateli (Web-o3).

$\mathrm{Na}$ rosnący poziom biedy niepokojąco wpłynęły przemiany, jakie w ostatnich latach dotknęły światową ekonomię. W raporcie Klubu Rzymskiego Pieniadze i zrównoważoność, brakujące ogniwo podano, że aż 98\% zawieranych codziennie transakcji finansowych nie jest związanych z produkcją, ale ze spekulacjami finansowymi. W tradycyjnym kapitalizmie surowce, fabryki i produkty miały swoją wartość monetarną. Obecnie o wiele więcej można zarobić nie produkując niczego, koncentrując się jedynie na obrotach wirtualnych pieniędzy. Na ten problem zwrócił uwagę papież Franciszek w 2014 roku podczas audiencji dla uczestników sympozjum na temat inwestowania w działania na rzecz najuboższych. Powiedział wtedy: „Nie możemy dłużej tolerować tego, że rynki finansowe decydują o losach narodów zamiast zaspokajać potrzeby, a także tego, że nieliczni prosperują, uciekając się do spekulacji finansowych, podczas gdy wielu boleśnie odczuwa ich konsekwencje" (Web-04). Słowa te potwierdził w orędziu na Wielki Post w 2016 roku, krytykując modele tzw. fałszywego rozwoju, oparte na kulcie pieniądza prowadzącego do zobojętnienia na los ubogich (Web-05).

Kolejną ważną kwestią, do której odnosi się encyklika Laudato si', jest zadziwiające przyspieszenie, jakie obserwujemy we współczesnym świecie: „Nieustannie wzrastająca szybkość przemian ludzkości i naszej planety łączy się dziś z intensyfikacją rytmu życia i pracy w tym, co niektórzy nazywają przyspieszeniem. Choć zmiany należą do dynamiki złożonych systemów, prędkość, jaką im narzucają ludzkie działania, kontrastuje dziś z naturalną powolnością ewolucji biologicznej. Dołącza się do tego problem, iż cele tych szybkich i ciągłych zmian niekoniecznie są zorientowane na dobro wspólne i ludzki rozwój, zrównoważony i integralny. Zmiana jest czymś pożądanym, ale budzi niepokój, kiedy prowadzi do degradacji świata i jakości życia znacznej części ludzkości”. Wyzwaniem nie jest tylko ogromna szybkość, z jaką wszystko wokół nas się zmienia, ale także jej konsekwencje. Jesteśmy zalewani coraz większą ilością informacji, często ze sobą sprzecznych, coraz trudniej nam o spojrzenie całościowe, dające podstawę do właściwej diagnozy. Warto dodać, że w ekonomii w 1999 roku wprowadzono nawet termin turbokapitalizm, który ma właśnie odzwierciedlać gwałtowność i skalę zachodzących zmian (Luttwak 1999).

Na szczęście nie jesteśmy bezsilni. Papież przedstawia konkretne postulaty, które powinny być spełnione dla wspólnego dobra: „Trzeba, aby kraje rozwinięte przyczyniły się do rozliczenia długu wobec środowiska, znacznie ograniczając zużycie energii nieodnawialnej i zapewniając środki krajom najbardziej potrzebującym, aby promować poczynania i programy na rzecz zrównoważonego rozwoju. [...] W kwestii zmian klimatycznych mamy do czynienia ze zróżnicowaną odpowiedzialnością, [...] stosowne byłoby skupienie się «zwłaszcza na potrzebach ubogich, słabych i kruchych, w debacie często zdominowanej przez potężne interesy». Trzeba umocnić świadomość, że jesteśmy jedną rodziną ludzką. Nie ma granic ani barier politycznych lub społecznych, które pozwalają nam na izolowanie się i właśnie dlatego nie ma miejsca na globalizację obojętności”.

Bardzo ważne jest w tym fragmencie odniesienie do zróżnicowanej odpowiedzialności. Większość współczesnych zagrożeń środowiskowych wynika bowiem 
z dotychczas niezrównoważonego rozwoju krajów bogatej północy. Mieszka w nich zaledwie jedna piąta ludzkości, ale zarazem to właśnie one zużywają 70\% dostępnej energii, 75\% metali i 85\% drewna (Schnoor 2003: 119A). Zasoby te w zatrważającym stopniu są marnotrawione. Amerykańskie szacunki wskazują, że 93\% surowców zużywanych w USA „[...] nie jest przetwarzanych w towary handlowe. Poza tym, aż 80\% zasobów wyrobów gotowych wyrzucanych jest już po jednorazowym użyciu, a pozostałe nie są tak trwałe, jak powinny być" (Weizsacker 1999: 10). Dodajmy, że w wymiarze środowiskowym kraje północy przeszły na swej drodze czas bezwzględnego niszczenia środowiska, acz na usprawiedliwienie dodajmy do pewnego stopnia nieuświadomionego. Obecnie wymagają one od krajów biednych, aby tego środowiska nie niszczyły. Zarazem jednak pomoc dla południa jest dość ograniczona i to mimo ogromnej dysproporcji ekonomicznej: dochód krajów najbiedniejszych to tylko 1,9\% tego, co mają najbogatsi (Wise 2001: 131-138).

Czy w tej sytuacji kraje biedne faktycznie mają brać na siebie obowiązek wyrzekania się na rzecz środowiska? Czy mają szansę uniknięcia błędów popełnionych przez północ? Ponadto, czy sama północ jest gotowa do przeprowadzenia bardziej radykalnych zmian wobec siebie? Do takiej zmiany wzywa papież Franciszek.

Szczególne wyzwanie na tej drodze stanowi zjawisko globalizacji. Współcześnie określa się ją jako zintegrowany, światowy system społeczno-gospodarczy, powiązany z wielkimi korporacjami, charakteryzujący się ponadpaństwową (i ponadnarodową) „dyfuzją kapitału i przyjęciem zasady wolnego handlu w dziedzinie gospodarki (globalizacja ekonomiczna) oraz upodabnianiem się wzorców kultury, szczególnie w wydaniu masowym (globalizacja kulturowa)" (Gawor 2006: 41-42).

Duże korporacje stanowią przeszkodę we wdrażaniu zrównoważonego rozwoju, nastawione są bowiem przede wszystkim na zysk i przybrały charakter ponadnarodowy, postnarodowy, a poniekąd także antynarodowy (Barber 2007), przez co osłabiły rolę, jaką do tej pory odgrywały poszczególne państwa. Jeżeli przyjęte w danym kraju czy grupie krajów (nawet na poziomie UE) rozwiązania i strategie są z punktu widzenia tych korporacji niekorzystne, to tę część aktywności przeniosą na teren innych państw, gdzie takie działania mogą być dopuszczalne (Ikerd 2005). To jest właśnie wspomniana w encyklice globalizacja obojętności, zwana też globalizacją ekskluzywną, odwołująca się do aksjologii egoistycznej, w ramach której liczy się tylko zysk, a „moralność i etyka nie istnieją" (Weizsacker 1999: 260). W opublikowanym w 2000 roku amerykańskim opracowaniu Global Trends 2015 globalizację ekskluzywną określono jako nie tylko szkodliwą, ale też stanowiącą zagrożenie dla dalszego trwania ludzkości (Web-o6). Wskazanie to nie zostało zakwestionowane do dziś.

Zauważmy jednak za Janem Pawłem II, że globalizacja nie jest „a priori dobra ani zła. Będzie taka, jaką uczynią ją ludzie” (Jan Paweł II 2001). Dlatego wobec dominującej globalizacji obojętności dla biednych na forum ONZ promuje się rozwiązanie alternatywne - globalizację inkluzywną (Annan 1997), odwołującą się do aksjologii ekohumanistycznej i zgodnej z koncepcją zrównoważonego rozwoju. I to jest także droga, którą wskazuje papież Franciszek.

\section{Zakończenie}

Bez wątpienia obecny czas jest jednym z przełomowych momentów w dziejach ludzkości. Przepaść między północą a południem pogłębia się, nieustannie wybuchają nowe konflikty zbrojne, których konsekwencją jest m.in. niespotykana fala uchodźców zmierzających do Europy. Jak jednak pisze papież w encyklice Laudato si', „wszystko może się zmienić”, a istotną rolę w tej przemianie odegrać ma konsekwentne wdrażanie integralnego rozwoju zrównoważonego. Zacytujmy jeszcze jeden fragment encykliki Laudato si’: „Aby osiągnąć zrównoważony rozwój, ochrona 
środowiska powinna stanowić nierozłączną część procesu rozwoju i nie może być rozpatrywana oddzielnie. Ale równocześnie pilna staje się potrzeba humanizmu odwołującego się do różnych dziedzin wiedzy, w tym do ekonomii, by wypracować wizję bardziej wszechstronną i integrującą". Humanizm nie wykluczający, a integrujący - to wszak kwintesencja koncepcji zrównoważonego rozwoju!

\section{Bibliografia}

Annan A. 1997. Renewing the United Nations: a programme for reform. New York: UN.

Barber B.R. 2007. Dżihad kontra Mc Świat. Warszawa: Muza S.A.

Benedykt XVI. 2009. Caritas in veritate. Watykan.

Borys T. 1998. Teoretyczne aspekty konstruowania wskaźników ekorozwoju. W B. Poskrobko (red.). Sterowanie ekorozwojem, vol. 1, 74-75. Wydawnictwo Politechniki Białostockiej.

Franciszek (papież). 2016. Laudato Si'. Watykan.

Gawor L.. 2006. „Antyglobalizm, alterglobalizm i filozofia zrównoważonego rozwoju jako globalizacyjne alternatywy". Problemy Ekorozwoju 1(1): 41-42.

Ikerd J.E. 2005. Sustainable Capitalism: A Matter of Common Sense. Bloomfield: Kumarin Press Inc. Jan Paweł II. 1987. Sollicitudo rei socialis. Watykan. Jan Paweł II. 2001. Wypowiedź na VII Sesji Plenarnej Papieskiej Akademii Nauk Społecznych, która odbyła się w Watykanie w dniach 25-27 IV 2001 r.

Luttwak E. 1999. Turbo-Capitalism: Winers and Losers in the Global Economy. New York: Harper Collins.

Schnoor J.L. 2003. „An environmental challenge”. Environmental Science and Technology 1.04.2003, 119A.
Wise T.A. 2001. Global perspecitves: the north/ south imbalance. W J.M. Harris, N.R. Goodwin (red.). A Survey of Sustainable Development: Social and Economic Dimensions. Frontier Issues in Economic Thought, 81. Washington, Covelo, London: Island Press.

Von Weizsacker E.U., Lovins A.B., Lovins L.H.. 1999. Mnożnik cztery: podwojony dobrobyt - dwukrotnie mniejsze zużycie zasobów naturalnych. Nowy raport dla Klubu Rzymskiego. Toruń: Polskie Towarzystwo Współpracy z Klubem Rzymskim.

\section{Witryny internetowe}

(Web-01) Johnson D.J. 2002. Sustainable Development: Our Common Future, OECD Observer nr $8,<$ http://www.oecdobserver.org/news/printpage. php/aid/780/Sustainable_development:_Our_ common_future.html>, dostęp: 1.02.2016.

(Web-02) Hiszpania: praca za miejsce do spania $i$ wyżywienie http://biznes.onet.pl/praca/bezrobocie/ hiszpania-praca-za-miejsce-do-spania-i-wyzywienie/xldxt, dostęp: 1.02.2016.

(Web-03) National Poverty Center <http://www.npc. umich.edu/poverty/>, dostęp: 1.02.2016.

(Web-04) Franciszek, Rynki finansowe nie moga decydować o losach ludzi <http://www.bankier. $\mathrm{pl} /$ wiadomosc/Papiez-rynki-finansowe-nie-moga-decydowac-o-losach-ludzi-3146662.html>, dostęp: 1.02.2016.

(Web-05) Franciszek, Orędzie Ojca Świętego Franciszka na Wielki Post 2016 roku <https://w2.vatican.va/content/francesco/pl/messages/lent/ documents/papa-francesco_20151004_messaggio-quaresima2016.html>, dostęp: 1.02.2016.

(Web-06) National Intelligence Council, Global Trends 2015: A Dialogue About the Future with Nongovernment Experts, <http://infowar.net/cia/ publications/globaltrends2015>, dostęp: 1.02.2016. 


\section{Sustainable Development Idea in Laudato Si' Encyclical}

\section{Summary}

The Laudato Si' encyclical is the most important document of the Catholic Church in recent years. Discussing the problem of endangered proper development of human society, Pope Francis refers to the idea of sustainable and integral development, showing the link between environmental problems and general issues, economic and social. He emphasizes the importance of the growing gap between the rich and the poor, calling for respect towards the basic needs and rights of the whole human family. The Pope advocates rejection of exclusive globalization, arguing that this change is possible - for the common good of us all.

\section{Key words}

Laudato Si' encyclical, sustainable development, Catholic Church, justice 